\title{
Study of polyphenols, antioxidant capacity and minerals for the valorisation of ancient apple cultivars from Northeast Italy
}

\author{
Raffaella Preti ${ }^{1} \cdot$ Anna Maria Tarola $^{1}$
}

Received: 23 July 2020 / Revised: 22 September 2020 / Accepted: 27 September 2020 / Published online: 6 October 2020

(c) The Author(s) 2020

\begin{abstract}
Nutritional properties and quality of apple fruits can be related to presence of secondary metabolite contents such as phytochemicals and mineral elements. In this paper, eight polyphenols, four major minerals ( $\mathrm{Na}, \mathrm{K}, \mathrm{Mg}, \mathrm{Ca}$ ), total phenolic content and antioxidant capacity were determined in fourteen ancient apple cultivars grown in Friuli Venezia Giulia (Northeast Italy) to highlight their nutraceutical properties. Both apple peel and pulp were examined separately and results were compared to those of six widespread commercial cultivars using principal component analysis. Ancient apples had much higher content in healthful compounds with respect to commercial varieties, particularly in the peel. Ancient cultivars showed a superior antioxidant capacity in peel (3- to 9- fold) and in pulp (2- to 5-fold) compared to commercial cultivars, with a good correlation with total phenolic content $(R=0.83$ in peel and 0.69 in pulp). The polyphenols that mostly characterized the ancient apples pulp were catechins and flavonols. Regarding macro elements, $\mathrm{K}$ and $\mathrm{Mg}$ content were higher in ancient cultivars, while $\mathrm{Na}$ and $\mathrm{Ca}$ showed no significant differences. In the perspective of a sustainable economic and social development of local agricultural realities, these results contribute to the valorisation of ancient local apple cultivars as invaluable reservoir of genetic biodiversity to be promoted as functional food or exploited in breeding novel apple hybrids with high nutraceutical properties and better resistance to parasites.
\end{abstract}

Keywords Polyphenols $\cdot$ Minerals $\cdot$ Ancient cultivars $\cdot$ Antioxidant capacity $\cdot$ Apple $\cdot$ Principal component analysis

\section{Introduction}

Apple (Malus $\times$ domestica Borkh) is one of the most appreciated fruit consumed worldwide. Its success is linked above all to its good taste, availability all year round and nutritional properties. Apple can be evaluated for its nutraceutical properties that can be related, more than to a specific compound, to its whole phytocomplex. Polyphenols have gained special attention in fruit and vegetables because their association with an improved antioxidant activity both in vitro and in vivo related to their ability to scavenge free radicals $[1,2]$.

The main polyphenols found in apples are anthocyanins, dihydrochalcones, flavanols, flavonols, hydroxybenzoic acid and hydroxycinnamic acid that play an important role in the healthful properties of apples [3-5].

Raffaella Preti

raffaella.preti@uniroma1.it

1 Department of Management, Laboratory of Commodity

Science, Sapienza University of Rome, Via del Castro

Laurenziano 9, 00161 Rome, Italy
Mineral ions are of prime importance in determining the fruit nutritional value, the major ones being potassium $(\mathrm{K})$, calcium $(\mathrm{Ca})$, sodium $(\mathrm{Na})$ and magnesium $(\mathrm{Mg})$. Required amounts of these elements must be introduced regularly in human diet, as they help the human body work as it should and fight off illness and diseases [3, 6]. Minerals content and balance in fruit play also a key role in preserving fruit quality during storage, retarding senescence and damages [3]. Mineral composition of fruit is less reported in literature in comparison to other compounds, despite this information is of high importance for nutritional and agronomic purposes.

Phenolic compounds and major minerals profile and content in fruit depends on fruit cultivar, ripeness, physiological condition as well as soil and weather conditions, but also on postharvest conditions, as storage and processing. Furthermore, pulp and peel contents of secondary metabolites are different both from qualitative and quantitative point of views. Since the peel is the richest source of phenolics, any promotion of apple consumption should imply this fruit part $[5,7,8]$. 
It is estimated that in the world there are at least 3000 varieties of apples, so we can make them immediately realize how in reality the choice we have is really limited. The market choices has been driven towards apples with good looking and high resistance to storage, and apple genetic variability has been impoverished by a narrow selection of varieties since most of the apples in the market derives from only six cultivars with favorable sensory attributes [9, 10]. Commercial apples have shown to have a lower content in bioactive compounds respect to traditional cultivars [11-13]. This fact has been attributed to the association between polyphenolic content with rapid enzymatic browning in apple pulp [14-16], and with unpleasant astringent taste. Therefore, the result of the breeding selection of fruits with ideal organoleptic qualities were commercially attractive varieties but with reduced polyphenols content [17].

On the contrary ancient apple cultivars have shown high antioxidant capacity and high content in polyphenols, in several countries, Poland [18], Croatia [19], Germany [17] and Austria [11].

Ancient apple cultivars are still produced in Italy in local orchards, with 1000 varieties produced in the Italian territory, but about ten commercial varieties cover over $70 \%$ of the entire market [20]. The bioactive compounds content of Italian old apple has been studied in Central Italy [21], South Italy [22], Friuli Venezia Giulia region [5] and Garfagnana region [4]. These studies reported significant high amount of antioxidant compounds in ancient cultivars.

Up to our knowledge, there are few studies concerning the study of dietary elements in ancient apples. For Italian varieties, a research was carried out by Agnolet et al. [9] in Sud Tyrol but only in apple pulp and more recently, Wandjou et al. characterized the ancient Italian variety 'Mela Rosa Dei Monti Sibillini' for mineral, polyphenols and volatiles [23]. In Chile, Henriquez et al. [24] studied both antioxidant properties and elemental content in both peel and pulp, Feliciano et al. examined Portuguese apples for phytochemicals, minerals and sensory attributes [25] and in 2014 Todea et al. [26] determined minerals and polyphenols in apples grown in Romania.

Consumers are becoming more aware of the importance of a high intake of antioxidants and beneficial elements in diet, therefore pay attention to food rich in bioactive compounds and naturally grown, free of chemical substances. The recovery of ancient apple cultivars due to their peculiar composition, taste, resistance to pathogens and adaptability to climate and soil can answer this demand.

In this context, the main purpose of this work is to investigate the profile and content in polyphenols of 14 ancient apple cultivars from Friuli Venezia Giulia region, an important production area of Northeast Italy and to complete the nutritional evaluation with the determination of major minerals, that has never been conducted on apples from this territory. Some selected cultivars from this area have been already investigated for polyphenols and triterpenes composition by Sut et al. [5], for polyphenols by Tarola et al. [27] and for the flavor composition by Giannetti et al. [28]. For the wide number of apple varieties cultivated in Friuli Venezia Giulia and the importance of this economic sector for the region, it is important to enlarge the knowledge of bioactive compounds on the greatest number of cultivars, as to estimate the best source of genes that can affect biological diversity in horticulture [11]. The sample set included six commercial cultivars chosen among the most representative of the Italian market to compare the results obtained. Characterization of cultivars in terms of antioxidant properties has been completed by in vitro assays of radical scavenging activity and total phenol content determination. Each apple was examined for pulp and peel separately.

\section{Materials and methods}

\section{Samples}

The 14 ancient apple cultivars studied in this study were: "Striato Dolce", "Bella Donna", Calvilla", "Da la Fraula", "Dal Cordon", "Da la Rosa", "Non Id", "Cigulin”, "Di Corone", "Calvilla Bianco", "Marcpanara", "Ruggine Dorata", Limoncei" and "Dal Doc". The samples were harvested by "Associazione Mele Antiche" located in Friuli Venezia Giulia Italy and were all organically grown. The samples were collected in late summer 2016, from three different trees for each variety, $2 \mathrm{~kg}$ per tree. Commercial apple samples were purchased in local market in Rome, Italy. The commercial apple cultivars analyzed were chosen among the most appreciated by consumer: Red Delicious, Golden Delicious, Royal Gala, and Fuji. A rediscovered and now widespread old variety Annurca, and a novel hybrid, Kanzi. After being washed, pulp and peels were separated and stored at $-20{ }^{\circ} \mathrm{C}$ until analysis. A part of the collected samples was quickly frozen in liquid nitrogen and lyophilized; samples were then ground to a powder and stored in airtight vials at room temperature.

\section{Standard and reagents}

Gallic acid, (+) catechin, (-) epicatechin, chlorogenic acid, phloridzin, quercetin, phloretin, rutin, 1,1-diphenyl2-picryl-hydrazyl (DPPH), formic acid, folin-ciocalteau reagent, sodium carbonate, methanol of HPLC grade, methanesulphonic acid (99\%), and hydrochloric acid (37\%) were purchased from Merck (Germany). Standard working calibration solutions for cation analysis were prepared daily by dilution from a Thermo Scientific Dionex Combined Six Cation II Standard (Dionex Corporation). 


\section{Mineral composition determination}

Cation analysis was performed by the method described by Cataldi et al. [29]. $\mathrm{Na}, \mathrm{K}, \mathrm{Mg}$ and $\mathrm{Ca}$ were extracted by suspending a weighed amount $(12.5 \mathrm{mg})$ of lyophilized tissue in $4.0 \mathrm{~mL}$ of $5 \mathrm{mM}$ hydrochloric acid. The suspension was shaken for $15 \mathrm{~min}$, and then centrifuged at $3000 \mathrm{rpm}$ for $10 \mathrm{~min}$ and then passed through $0.45 \mu \mathrm{m}$ filters before being injected.

The chromatographic determination was performed using a Thermo Scientific Dionex Ion Chromatography SystemICS 1100 equipped with a suppressed conductivity detector. Isocratic separation was carried out on an IonPac CS12A analytical column (4 $\mathrm{mm}$ i.d.), the mobile phase being an aqueous solution containing $20 \mathrm{mM}$ methanesulfonic acid.

\section{Determination of polyphenols}

\section{Sample extraction}

The extraction procedure followed that reported previously by Tarola et al. [27]. Briefly, the apple samples of peel and pulp have been separated and the pulp (5 g) and the peel $(5 \mathrm{~g})$ fractions were immediately homogenized with methanol containing $1 \%$ hydrochloric acid. The samples have been extracted with $10 \mathrm{ml}$ of solvent for $30 \mathrm{~min}$ and $10 \mathrm{ml}$ for $30 \mathrm{~min}$ using an Ultrasonic sonicator at room temperature $\left(25^{\circ} \mathrm{C}\right)$. The extract, pulp and peel separately, were combined and filtered through a membrane $0.45 \mu \mathrm{m}$ pore size prior to injection in HPLC for determining the individual phenolic compounds, antioxidant activity and total phenolics.

\section{Identification and quantification of individual phenolic compounds}

HPLC analyses were performed on a Shimadzu HPLC system, a LC-10AT liquid chromatograph equipped with four pumps FCV-10AL, a degasser DGU-14A and a photodiode array detector SPD-M20A.

The column used was a C18 Kinetex $(150 \mathrm{~mm} \times 4.6 \mathrm{~mm}$, $5 \mu \mathrm{m}$ particle size), and a guard column, all supplied by Phenomenex (Torrance, CA, USA). The mobile phase was a mixture: $2 \%$ acetic acid in water (solvent $\mathrm{A}$ ) and acetonitrile (solvent B). The eluted compounds were monitored at 280 , 320 and $350 \mathrm{~nm}$ and the adsorption spectra between 200 and $600 \mathrm{~nm}$.

\section{DPPH radical scavenging activity}

Aliquots $(200 \mu \mathrm{L})$ of extracts were added to $3 \mathrm{~mL}$ of DPPH solution $(6 \times 10-5 \mathrm{~mol} / \mathrm{L})$ and the absorbance was determined at $515 \mathrm{~nm}$ after $30 \mathrm{~min}$. The DPPH radical scavenging activity of apple extracts was expressed as micrograms of gallic acid equivalents per gram of fresh peel or pulp $(\mathrm{GAE}=$ gallic acid equivalent antioxidant capacity).

\section{Determination of total phenols content}

Total phenolics content was determined using the Folin-Ciocalteau method according to Singleton et al. [30]. Total phenolics content was expressed as milligrams GA equivalent (GAE) per gram FW.

\section{Statistical analysis}

The quantifications of polyphenols, total phenolic content and antioxidant capacity in apples were carried out in triplicate. Range, mean and standard deviation (SD) for every type of sample were calculated.

One-way analysis of variance (ANOVA) was performed and means were separated by least significant difference test (LSD) at $p \leq 0.05$, using the statistical analysis system (SAS Ver. 9.0). Correlation analysis was performed, and the Pearson correlation coefficient was calculated.

Principal component analysis (PCA), was applied to highlight a natural grouping of samples depending on their different antioxidant capacity and antioxidants content in relation to the different cultivars. All the computations were performed using V-PARVUS [31].

\section{Results and discussion}

\section{Polyphenols content}

In this study eight polyphenols compounds were determined in 20 apple samples, 14 ancient cultivars and 6 commercial cultivars, using retention times and absorption maxima of reference compounds. The analysis were performed on apple peel and pulp, separately (Tables 1,2). As emerged in previous studies, peel had a significantly greater content in polyphenols respect pulp. Higher concentration of phenolics, carotenoids and ascorbic acid in fruit peel has been reported in other fruit, and probably is attributable to their role in defense against pathogens and UV radiations $[1,5,7]$.

The sum of the eight single polyphenols ranged between 18.33 (Marcpanara) and $48.01 \mathrm{mg} / 100 \mathrm{~g}$ (Ruggine Dorata) in ancient apple pulp, while between 12.38 (Kanzi) and $22.1 \mathrm{mg} / 100 \mathrm{~g}$ (Royal Gala) in commercial apples pulp.

Polyphenols content in ancient apples peel ranged from 51.38 (Calvilla Bianca) to $146.63 \mathrm{mg} / 100 \mathrm{~g}$ (Di Corone) and 43.45 (Kanzi) - $74.55 \mathrm{mg} / 100 \mathrm{~g}$ (Fuji), in commercial apples peel. Interestingly, the average content in ancient apples peel resulted to be almost tripled $(85.42 \mathrm{mg} / 100 \mathrm{~g}$ FW) than in pulp (30.46 mg/100 g FW) and quadrupled in 


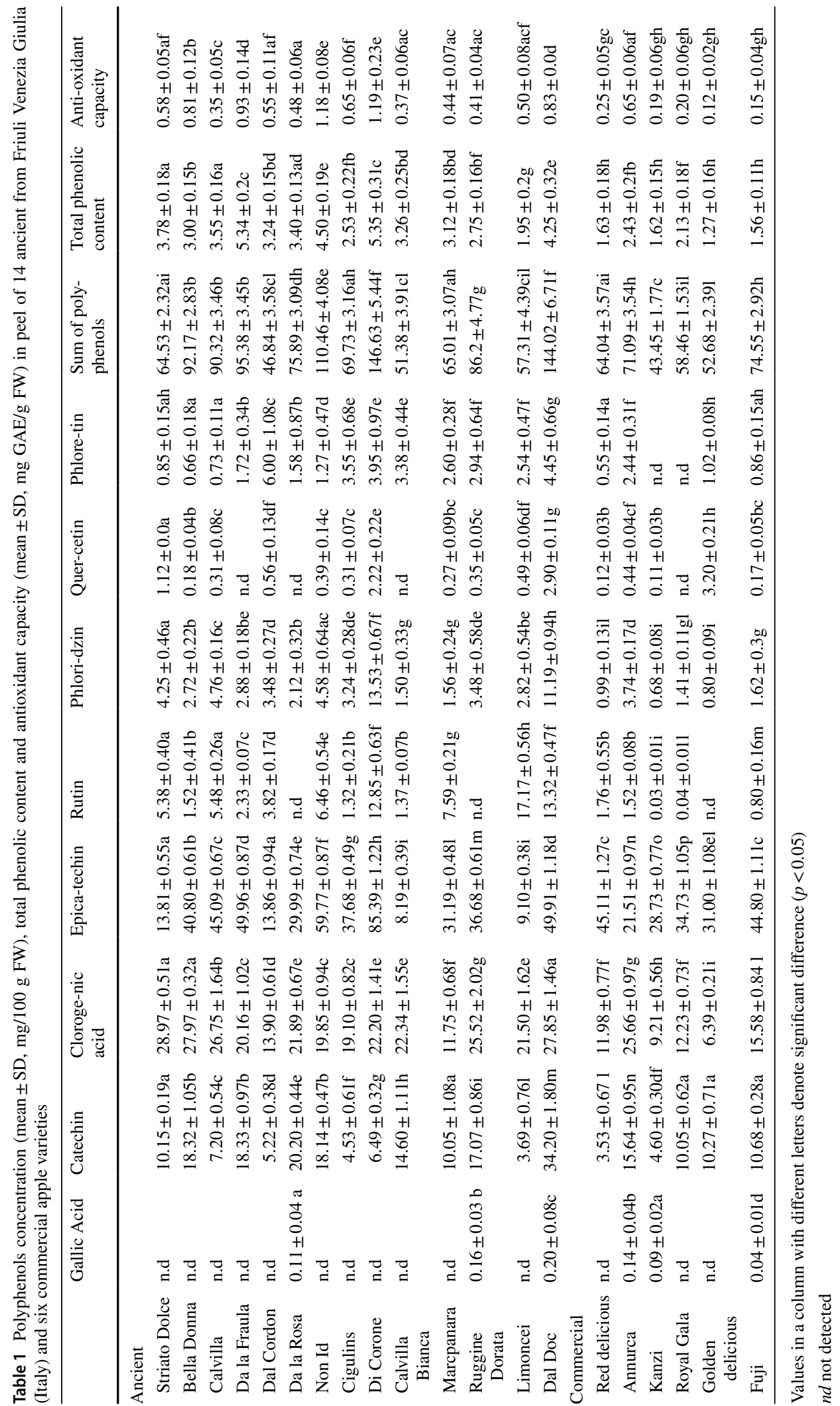




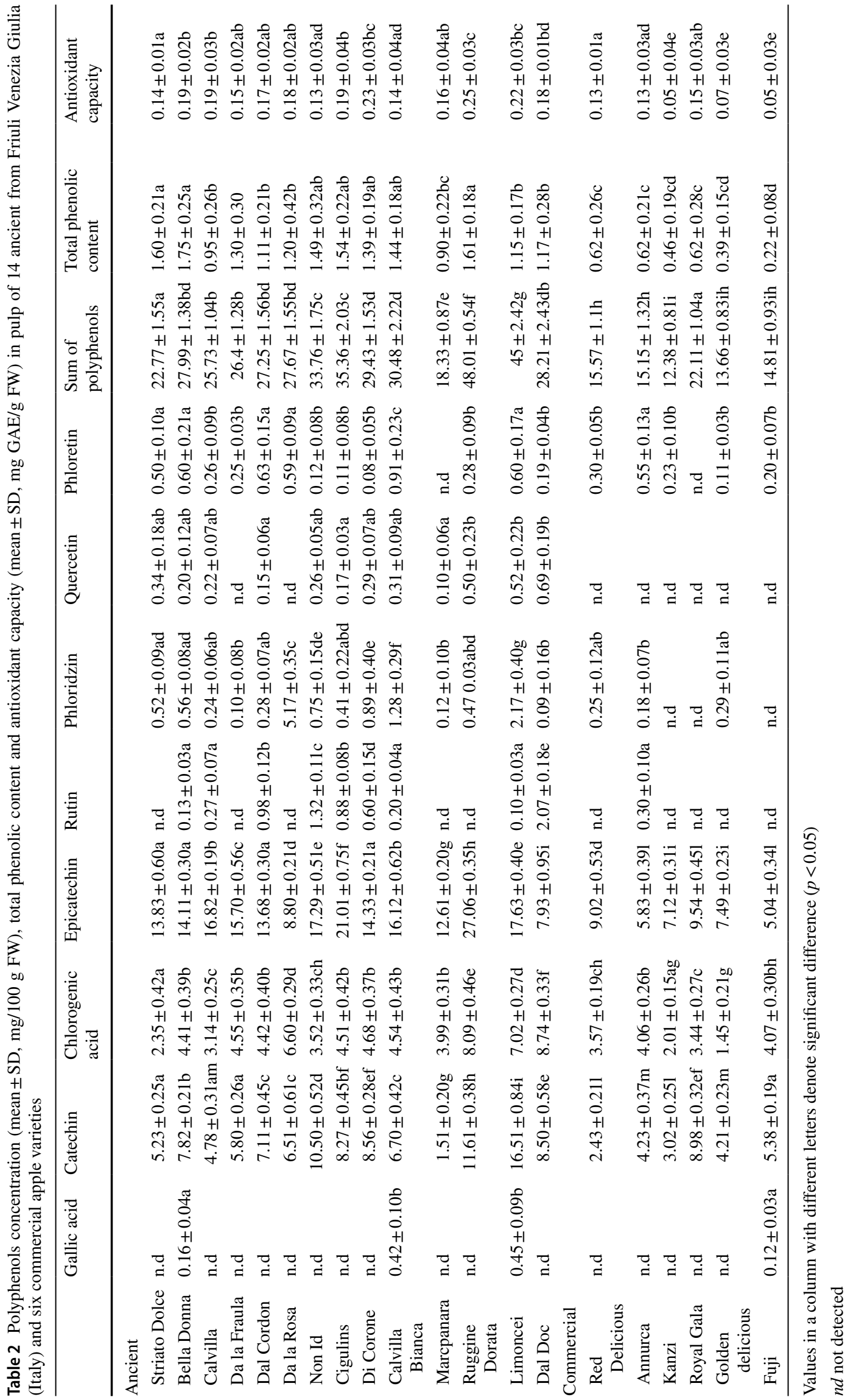


commercial apples (60.71 vs $15.61 \mathrm{mg} / 100 \mathrm{~g} \mathrm{FW})$. These evidences can lead to the hypothesis that the breeding selection has been mainly focused on the improvement of the organoleptic properties of pulp, as it represents the main consumed part of the apple, resulting in a more marked reduction of polyphenols [17].

Among the polyphenols analyzed, catechins are the most present, reaching a value of $27.06 \pm 0.35 \mathrm{mg} / 100 \mathrm{~g}$ FW for epicatechin in Ruggine Dorata pulp and of $85.39 \pm 1.22 \mathrm{mg} / 100 \mathrm{~g}$ FW for Di Corone peel. Catechin is the second compound in pulp with an amount of $16.51 \pm 0.84 \mathrm{mg} / 100 \mathrm{~g}$ FW in Limoncei and of $27.06 \pm 0.35 \mathrm{mg} / 100 \mathrm{~g}$ FW in Ruggine Dorata variety.

In peel extracts, chlorogenic acid was the second most present phenolic compound with Striato Dolce $(28.97 \pm 0.51 \mathrm{mg} / 100$ g) Bella Donna $(27.97 \pm 0.32 \mathrm{mg} / 100 \mathrm{~g})$ and Dal Doc $(27.85 \pm 1.46 \mathrm{mg} / 100 \mathrm{~g})$ varieties. Regard to the other phenolic acid, gallic acid is poorly present in all samples studied. Chlorogenic acid exhibit anticarcinogenic, antimutagenic and antioxidant properties, and an antidiabetic activity but it is scarcely absorbed in the human body as it is metabolized mainly by colonic microflora $[18,32]$. Ancient cultivars apples from Friuli Venezia Gulia have been previously reported as a good source of chlorogenic acid [5] as to be an alternative to green coffee.

Dihydroclacones, phloridzin and phloretin, were mostly present in peel, with high prevalence in ancient apples varieties, as already reported in apples grown in Friuli Venezia Giulia [5], with the highest content in Di Corone peel for phloridzin $(13.53 \pm 0.67 \mathrm{mg} / 100 \mathrm{~g})$ and in Dal Cordon $(6.0 \pm 1.08 \mathrm{mg} / 100 \mathrm{~g})$ for phloretin. Noteworthy, the high phloridzin content in Dalla Rosa pulp (5.17 \pm 0.35$)$ $\mathrm{mg} / 100 \mathrm{~g}$ FW. Apple consumption has been shown to be effective at ameliorating intestinal inflammation symptoms. These beneficial effects have been related to polyphenols, including phloretin and its glycoside phloridzin, compounds found exclusively in apples. Phloridzin can inhibit lipid peroxidation and has been proposed as antihyperglycemic and antihyperlipidemic agent in diabetes and potential therapeutic in obesity [33].

Moreover, from an agronomic point of view, phloridzin can cause low susceptibility of apple fruit to the most important diseases and provides resistance to the common apple pathogens-Venturia inaequalis and Erwinia amylovora [34]. These properties can be exploited in the view of a reduction of phytochemicals, for a more sustainable production.

The flavonol rutin and its aglycone quercetin were scarcely reported in commercial apples pulp, except for Annurca. and in Friuli Venezia Giulia ancient [5]. In peel extracts, the glycosylated form, rutin, prevailed over the free form, quercetin, with Limocei variety that showed the highest amount of rutin $(17.17 \pm 0.56 \mathrm{mg} / 100 \mathrm{~g} \mathrm{FW})$. These data are particularly relevant because majority of previous studies did not reveal flavonols in pulp of ancient apples [7, 19,21], while the presence of quercetin in Annurca pulp has already been reported [35].

Quercetin is an important antioxidant compound which exhibits cardiovascular protection and cancer prevention properties [36]. Dal Doc variety is particularly rich in this flavanol both in peel and pulp.

The results hereby reported are in good accordance with those reported previously in Italian [7, 23, 37], Croatian [12] and Polish [18] apple varieties, while are not consistent to those reported in peel from other cultivars from the same Italian region that did not show any differences in catechin and flavonoid content when compared to commercial apples [5].

Among commercial apples, Annurca has a peculiar polyphenolic profile, that are mostly present in the peel, remarkable especially the good content in dihydrocalcones, these results are in accordance to previous reported data on this cultivar which is a rediscovered ancient apple for its nutraceutical properties.

\section{DPPH scavenging activity and total phenolic content}

To provide a complete description of the antioxidant properties of the apple samples object of the present study, DPPH scavenging activity essay and the Folin Ciocalteau essay for an estimation of the total phenolic content were also performed on their extracts

The results are presented in Tables 1 and 2 as mean \pm SD mg GAE/g FW. The data on peel extract show a great variability among varieties with the highest activity and phenolic content found in ancient apples. The highest antioxidant activity was measured in Di Corone $(1.19 \pm 0.23 \mathrm{mg}$ GAE$/ \mathrm{g} \mathrm{FW})$ and Non Id $(1.18 \pm 0.08 \mathrm{mg}$ $\mathrm{GAE} / \mathrm{g} \mathrm{FW}$ ) peel extract while total phenols highest amount was found in Di Corone $(5.35 \pm 0.31 \mathrm{mg} \mathrm{GAE} / \mathrm{g} \mathrm{FW})$ and Da La Fraula (5.34 $\pm 0.20 \mathrm{mg}$ GAE/g FW) peel extract. Pulp extracts have a smaller variability in both the essays with strong differences between ancient and commercial apples results. Antioxidant capacity ranged from $0.05 \pm 0.03 \mathrm{mg}$ GAE/g FW (Kanzi) to $0.15 \pm 0.03 \mathrm{mg} \mathrm{GAE} / \mathrm{g} \mathrm{FW}$ (Royal Gala) respect to $0.13 \pm 0.03 \mathrm{mg} \mathrm{GAE} / \mathrm{g} \mathrm{FW}$ (Non Id) and $0.25 \pm 0.03 \mathrm{mg} \mathrm{GAE} / \mathrm{g}$ FW (Ruggine Dorata). Total phenolic content followed the same trend, with the highest content in Bella Donna $(1.75 \pm 0.25 \mathrm{mg}$ GAE/g FW) and the lowest in Marcpanara $(0.90 \pm 0.22 \mathrm{mg} \mathrm{GAE} / \mathrm{g} \mathrm{FW})$, among ancient varieties. Among new varieties, ranged from $0.62 \pm 0.28 \mathrm{mg}$ GAE/g FW in Royal Gala to $0.22 \pm 0.08 \mathrm{mg} \mathrm{GAE} / \mathrm{g} \mathrm{FW}$ in Fuji. 
Regarding the correlation study carried out among different parameters and tissues, total phenolic compounds content was positively correlated with antioxidant activity in apple pulp $(R=0.69)$ and peel $(R=0.83)$ and with the sum of the individual polyphenols determined in pulp $(R=0.74)$ and in peel $(\mathrm{R}=0.72)$. On the contrary, the correlation study on antioxidant capacity in pulp vs in peel and of total phenolic content in pulp vs in peel demonstrated a positive relation only in the commercial group of apples ( $R=0.65, R=0.62$, respectively). These data are consistent with the results found by Drogoudi et al. [38], while Henriquez et al. [24] reported positive correlation for total phenolics but no correlation for antioxidant capacity evaluated by FRAP:

As previously observed by other researchers, the great difference between pulp and peel values and between ancient and commercial varieties seems to be linked to a higher concentration of total phenolics and flavonoids in ancient apples, and in peel in particular [4, 5, 22].

Moreover, it can be assumed from the data, that in each cultivar, particularly in ancient apples, there is a large variability among different tissue types [1,23], and this aspect must be considered to promote the consumption of the whole apple.

Respect to single polyphenols modest but significant correlations $(p<0.05)$ were found with epicatechin in pulp $(R=0.68)$ and in peel $(R=0.56)$, Chlorogenic acid in pulp $(R=0.66)$ and in peel $(R=0.55)$, phloretin only for peel $(R=0.69)$ and catechin only in pulp $(R=0.59)$.
These data confirm previous studies where catechin, epicatechin and chlorogenic acid are the major contributors to the antioxidant capacity of apples [4, 39]. The significant correlation between phloretin and antioxidant capacity has never been reported, it can be explained on the particularly high average content in phloretin of the apple varieties studied, and need further investigation.

\section{PCA analysis}

To better highlights similarities and differences among the apple cultivars examined, unsupervised pattern recognition technique such as principal components analysis (PCA) was used to evaluate the data matrices to highlight a natural grouping among samples. PCA was carried after autoscaling on the polyphenols, Total phenolic content and antioxidant capacity data matrix of apples extracts.

Bidimensional plots of sample scores and loadings in the space (defined by the first two principal components) are shown in Fig. 1.

In PCA for peel samples, the first two principal components (PC1 and PC2) accounted for $58.7 \%$ of the total variability. The variables that contributed more to the PC1 $(42.7 \%)$ were the antioxidant capacity, total phenolic content, phloridzin, quercetin, rutin and phloretin. The PC2 (16.0\%) was associated with gallic acid, catechin and chlorogenic acid.

Commercial apples resulted clearly separated from the ancient cultivar, resulting in the part with the lowest content
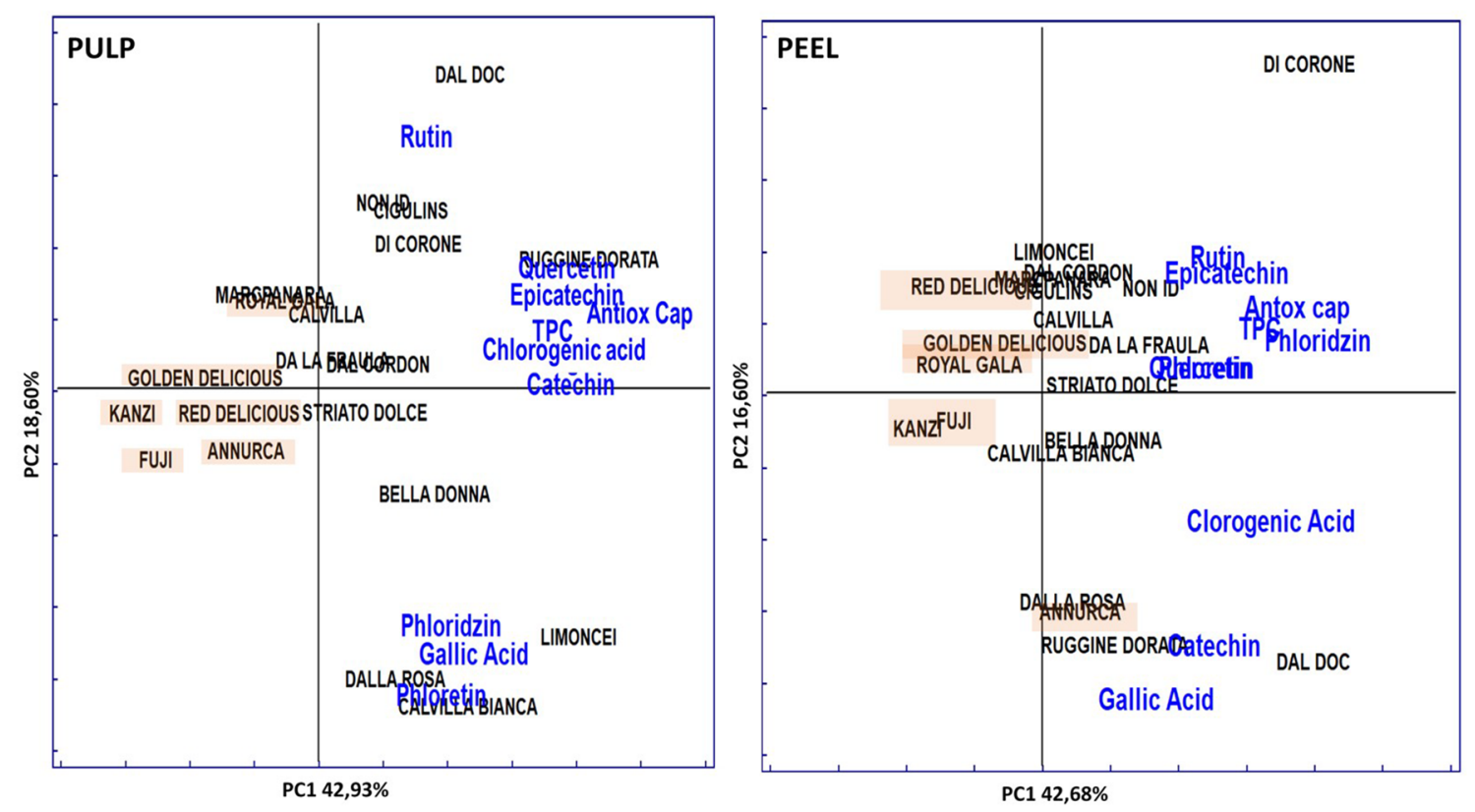

Fig. 1 Principal component analysis of polyphenols profile, antioxidant capacity and total phenols content (TPC) in commercial (highlighted in pink) and ancient apple cultivars from Friuli Venezia Giulia, pulp and peel 
of all the antioxidant, highlighting the big differences in antioxidants profile and content between the two groups. Interestingly, Annurca variety is, for peel extract, in the part with high gallic acid and catechin and therefore results similar to the ancient varieties Dalla Rosa and Ruggine Dorata. Two outliers are worth to be mentioned, Di Corone with its high content in phloridzin, epicatechin, phloretin and rutin, and from the opposite side of the graph Dal Doc cultivar with its high content in Chlorogenic acid and catechin. Ancient apples show a larger variability and are spread all over the graph.

Regarding the PCA for pulp samples, the first two principal components (PC1 and PC2) accounted for 61.5\% of the total variability.

The variables that contributed more to the PC1 (42.9\%) were the antioxidant capacity, total phenolic content, chlorogenic acid, quercetin, epicatechin and catechin. The PC2 (18.6\%) was associated with phloretin, phoridzin and gallic acid. Commercial apples were clearly separated, for the lower content in all the antioxidant parameters studied, in this case also Annurca pulp is included in the commercial apple group while Royal Gala can be included in a second group constituted by Striato Dolce, Da La Fraula, Dal Cordon, Calvilla and Marcpanara, characterized by a medium content of antioxidants. Non Id, Cigulins and Di Corone ancient varieties can be grouped with their high content in rutin and quercetin as discriminant. Interestingly, Dal Doc cultivar with its high amount of rutin and Ruggine Dorata and Limoncei with their peculiar pattern of antioxidants.

In the paper by Sut et al., ancient and commercial varieties were differentiated considering triterpene and phenolic derivatives in the dataset. In the present work, phenolic compounds and antioxidant capacity demonstrated to have a good discriminant power, able to separate the two groups both for peel and pulp data.

\section{Mineral elements}

There are remarkable differences in the content of the four minerals evaluated, both between different tissues, both between ancient and commercial apples, results are displayed in Table 3.

The mineral mostly present in the apples peel studied is $\mathrm{K}$ (media $160.3 \pm 51.44 \mathrm{mg} / 100 \mathrm{~g} \mathrm{FW}$ )

Table 3 Macroelements concentration (mean \pm SD, mg/100 g FW) in peel and pulp of 14 ancient from Friuli Venezia Giulia (Italy) and six commercial apple varieties. Values in a column with different letters denote significant difference $(p<0.05)$

\begin{tabular}{|c|c|c|c|c|c|c|c|c|}
\hline & $\mathrm{Na}$ & $\mathrm{K}$ & $\mathrm{Mg}$ & $\mathrm{Ca}$ & $\mathrm{Na}$ & $\mathrm{K}$ & $\mathrm{Mg}$ & $\mathrm{Ca}$ \\
\hline Ancient & & & Peel & & & Pulp & & \\
\hline $\begin{array}{l}\text { Striato } \\
\text { Dolce }\end{array}$ & $1.42 \pm 0.21 \mathrm{ah}$ & $103.30 \pm 3.18 \mathrm{a}$ & $6.74 \pm 0.80 \mathrm{ac}$ & $6.20 \pm 0.33 a$ & $1.15 \pm 0.07 \mathrm{a}$ & $93.64 \pm 1.61 \mathrm{a}$ & $2.17 \pm 0.12 \mathrm{adh}$ & $2.37 \pm 0.07 \mathrm{a}$ \\
\hline $\begin{array}{l}\text { Bella } \\
\text { Donna }\end{array}$ & $2.43 \pm 0.15 b$ & $236.00 \pm 14.44 b$ & $7.68 \pm 0.67 \mathrm{ac}$ & $4.27 \pm 0.30 b$ & $1.16 \pm 0.14 \mathrm{a}$ & $194.15 \pm 2.82 b$ & $2.94 \pm 0.25 b e$ & $1.96 \pm 0.06 b$ \\
\hline Calvilla & $1.43 \pm 0.09 \mathrm{ah}$ & $92.27 \pm 4.37 \mathrm{c}$ & $5.67 \pm 0.85 \mathrm{ag}$ & $2.72 \pm 0.33 \mathrm{ce}$ & $0.93 \pm 0.06 b$ & $82.68 \pm 1.74 \mathrm{c}$ & $2.01 \pm 0.19 \mathrm{am}$ & $2.10 \pm 0.17 \mathrm{c}$ \\
\hline $\begin{array}{l}\text { Da la } \\
\text { Fraula }\end{array}$ & $1.86 \pm 0.11 \mathrm{ce}$ & $171.58 \pm 3.24 \mathrm{~d}$ & $10.99 \pm 0.55 b$ & $1.60 \pm 0.15 \mathrm{dg}$ & $1.09 \pm 0.10 \mathrm{a}$ & $117.38 \pm 1.98 \mathrm{~d}$ & $2.51 \pm 0.33 \mathrm{cdh}$ & $1.29 \pm 0.10 \mathrm{~d}$ \\
\hline Dal Cordon & $1.87 \pm 0.06 \mathrm{ce}$ & $152.72 \pm 4.13 \mathrm{e}$ & $8.60 \pm 0.56 c$ & $4.56 \pm 0.15 b$ & $0.77 \pm 0.08 \mathrm{~cd}$ & $132.00 \pm 4.74 f$ & $2.90 \pm 0.15 \mathrm{bdf}$ & $2.56 \pm 0.05 \mathrm{e}$ \\
\hline Da la Rosa & $1.08 \pm 0.13 \mathrm{~d}$ & $138.20 \pm 4.09 \mathrm{f}$ & $1.75 \pm 0.50 \mathrm{~d}$ & $3.52 \pm 0.76 b$ & $0.89 \pm 0.06 b c$ & $122.43 \pm 3.71 \mathrm{~d}$ & $2.12 \pm 0.09 \mathrm{a}$ & $1.25 \pm 0.09 \mathrm{~d}$ \\
\hline Non Id & $1.91 \pm 0.09 \mathrm{cef}$ & $190.55 \pm 4.74 \mathrm{~g}$ & $6.87 \pm 0.85 \mathrm{ac}$ & $1.85 \pm 0.19 \mathrm{~d}$ & $0.70 \pm 0.10 \mathrm{fd}$ & $188.19 \pm 3.91 \mathrm{bi}$ & $2.97 \pm 0.11 \mathrm{be}$ & $1.30 \pm 0.05 \mathrm{~d}$ \\
\hline Cigulins & $1.68 \pm 0.15 \mathrm{c}$ & $209.23 \pm 5.89 \mathrm{~h}$ & $14.07 \pm 0.87 \mathrm{ef}$ & $3.83 \pm 0.06 b$ & $0.93 \pm 0.06 b$ & $207.80 \pm 2.45 \mathrm{~g}$ & $3.11 \pm 0.13 \mathrm{be}$ & $1.10 \pm 0.15 f$ \\
\hline Di Corone & $1.14 \pm 0.11 \mathrm{dh}$ & $187.29 \pm 4.14 \mathrm{~g}$ & $6.00 \pm 0.94 a$ & $1.74 \pm 0.16 \mathrm{dg}$ & $0.96 \pm 0.05 b$ & $165.58 \pm 3.37 \mathrm{~h}$ & $2.39 \pm 0.16 \mathrm{dgh}$ & $1.39 \pm 0.06 \mathrm{dl}$ \\
\hline $\begin{array}{l}\text { Calvilla } \\
\text { Bianca }\end{array}$ & $2.11 \pm 0.10 \mathrm{efg}$ & $188.64 \pm 5.87 \mathrm{~g}$ & $12.10 \pm 0.30 \mathrm{be}$ & $2.10 \pm 0.17 \mathrm{de}$ & $1.31 \pm 0.11 \mathrm{e}$ & $181.82 \pm 4.02 \mathrm{bi}$ & $3.20 \pm 0.22 \mathrm{e}$ & $1.28 \pm 0.03 \mathrm{~d}$ \\
\hline Marcpanara & $0.90 \pm 0.12 \mathrm{~d}$ & $208.61 \pm 3.04 \mathrm{~h}$ & $14.92 \pm 0.44 \mathrm{e}$ & $3.55 \pm 0.12 b$ & $0.51 \pm 0.10 \mathrm{f}$ & $200.85 \pm 6.341$ & $2.68 \pm 0.17 \mathrm{cf}$ & $1.30 \pm 0.08 \mathrm{~d}$ \\
\hline $\begin{array}{l}\text { Ruggine } \\
\text { Dorata }\end{array}$ & $2.16 \pm 0.10 \mathrm{fg}$ & $189.60 \pm 2.39 \mathrm{~g}$ & $6.50 \pm 0.36 a$ & $2.35 \pm 0.13 \mathrm{~cd}$ & $0.92 \pm 0.09 b$ & $170.41 \pm 5.46 \mathrm{~h}$ & $2.47 \pm 0.23 \mathrm{cdh}$ & $1.05 \pm 0.14 \mathrm{f}$ \\
\hline Limoncei & $2.36 \pm 0.11 \mathrm{bg}$ & $244.48 \pm 4.06 \mathrm{~b}$ & $15.17 \pm 0.67 \mathrm{e}$ & $6.10 \pm 1.73 a$ & $1.17 \pm 0.09 \mathrm{a}$ & $136.39 \pm 4.95 f$ & $2.16 \pm 0.11 \mathrm{agh}$ & $1.39 \pm 0.08 \mathrm{dl}$ \\
\hline Dal Doc & $1.40 \pm 0.12 \mathrm{~h}$ & $150.49 \pm 1.87 \mathrm{e}$ & $12.61 \pm 1.73 b f$ & $7.40 \pm 0.26 f$ & $0.68 \pm 0.07 \mathrm{fd}$ & $139.96 \pm 4.17 f$ & $2.41 \pm 0.07 \mathrm{~h}$ & $2.78 \pm 0.11 \mathrm{~g}$ \\
\hline \multicolumn{9}{|l|}{ Commercial } \\
\hline $\begin{array}{l}\text { Red } \\
\quad \text { delicious }\end{array}$ & $2.17 \pm 0.05 f g$ & $118.81 \pm 4.09 \mathrm{i}$ & $7.34 \pm 0.85 \mathrm{ac}$ & $3.81 \pm 057 b$ & $0.57 \pm 0.05 f$ & $100.29 \pm 4.09 \mathrm{a}$ & $1.80 \pm 0.11 \mathrm{im}$ & $1.42 \pm 0.111$ \\
\hline Annurca & $2.49 \pm 0.16 b$ & $77.87 \pm 3.101$ & $3.48 \pm 0.19 \mathrm{dg}$ & $1.42 \pm 0.11 \mathrm{~g}$ & $0.81 \pm 0.06 \mathrm{cbd}$ & $68.71 \pm 2.011$ & $0.75 \pm 0.18 n$ & $0.96 \pm 0.05 f$ \\
\hline Kanzi & $3.06 \pm 0.181$ & $116.24 \pm 2.36 \mathrm{i}$ & $2.12 \pm 0.27 \mathrm{~d}$ & $2.49 \pm 0.06 \mathrm{ce}$ & $0.80 \pm 0.08 \mathrm{cdb}$ & $116.66 \pm 2.52 \mathrm{~d}$ & $0.64 \pm 0.08 n$ & $1.60 \pm 0.13 \mathrm{~m}$ \\
\hline Royal Gala & $3.15 \pm 0.131$ & $144.39 \pm 2.09 \mathrm{ef}$ & $2.64 \pm 0.52 \mathrm{~d}$ & $5.84 \pm 0.345 a$ & $1.36 \pm 0.15 \mathrm{e}$ & $139.90 \pm 3.77 \mathrm{f}$ & $0.82 \pm 0.11 \ln$ & $1.51 \pm 0.11 \mathrm{~lm}$ \\
\hline $\begin{array}{l}\text { Golden } \\
\text { delicious }\end{array}$ & $2.10 \pm 0.10 \mathrm{ef}$ & $163.55 \pm 3.34 \mathrm{~d}$ & $2.69 \pm 0.36 d$ & $7.66 \pm 0.12 f$ & $0.75 \pm 0.09 \mathrm{~cd}$ & $160.43 \pm 3.08 \mathrm{~h}$ & $1.62 \pm 0.19 \mathrm{i}$ & $3.97 \pm 0.10 \mathrm{~h}$ \\
\hline Fuji & $2.76 \pm 0.11 \mathrm{i}$ & $191.26 \pm 5.07 \mathrm{~g}$ & $3.73 \pm 0.49 \mathrm{dg}$ & $5.64 \pm 0.21 \mathrm{a}$ & $1.11 \pm 0.14 \mathrm{a}$ & $185.28 \pm 5.02 \mathrm{i}$ & $1.09 \pm 0.121$ & $3.31 \pm 0.14 \mathrm{i}$ \\
\hline
\end{tabular}


followed by $\mathrm{Mg}$ (media $27.53 \pm 16.60 \mathrm{mg} / 100 \mathrm{~g} \mathrm{FW}$ ), $\mathrm{Ca}$ (media $13.39 \pm 6.94 \mathrm{mg} / 100 \mathrm{~g} \mathrm{FW}$ ) and $\mathrm{Na}$ (media $1.95 \pm 2.52 \mathrm{mg} / 100 \mathrm{~g} \mathrm{FW})$. The order of the elements is the same in pulp, but the amount is significantly inferior. In particular, the average amount resulted, in comparison of the peel average amount, the $27.79 \%$ for $\mathrm{Mg}, 46.90 \%$ for $\mathrm{Ca}$, $46.54 \%$ for $\mathrm{Na}$, and $88.75 \%$ for $\mathrm{K}$.

These data are in accordance with the those published by previous studies $[3,9,25,40]$, but result lower than those published by Henriquez et al. [24], except for K which results superior. Data from more recent article, examining mineral content in apples of different cultivars grown in Italy [23] and in Romania [26], are based on dry weight samples, so difficult to compare.

Literature data on traditional apples confirms the prevalence of minerals in apple peel, with 3-fold content of $\mathrm{Ca}$ and $\mathrm{Mg}$, 2-fold for $\mathrm{Na}$ and $30 \%$ more in K. Chilean traditional apples peel showed (showed on the contrary a prevalence of $\mathrm{Na}$ in the pulp (+50\%) [24].

Ancient apple cultivars present a higher amount in $\mathrm{K}$ and $\mathrm{Mg}$ respect commercial varieties peel, with also a larger variability. $\mathrm{K}$ is in media $175.98 \pm 44.77 \mathrm{mg} / 100 \mathrm{~g} \mathrm{FW}$ in ancient varieties, while is $123.72 \pm 50.52 \mathrm{mg} / 100 \mathrm{~g} \mathrm{FW}$ in commercial. $\mathrm{Mg}$ is $33.93 \pm 15.38$ vs $12.61 \pm 7.08 \mathrm{mg} / 100 \mathrm{~g}$ FW. Na is significant inferior in commercial apple peel of $35 \%$ while Ca media difference is not statistically different.

In pulp samples, $\mathrm{Na}$ and $\mathrm{Ca}$ content are similar between the two groups, while $\mathrm{K}(152.56 \pm 40.44$ vs $118.62 \pm 51.11 \mathrm{mg} / 100 \mathrm{~g}$ $\mathrm{FW})$ and $\mathrm{Mg}(9.21 \pm 1.36 \mathrm{vs} 4.01 \pm 1.73 \mathrm{mg} / 100 \mathrm{~g} \mathrm{FW})$ result always superior in ancient apples.

Differences among different cultivars are better explained by the PCA plot. In peel graph (Fig. 2) is clear how the commercial apples Golden delicious, Fuji, Royal Gala and Limoncei for the ancient apples have the highest amount in Na, while Dalla Rosa, Calvilla and Marcpanara peel for the ancient and Annurca for the commercial have the lowest. Annurca shows low content in all the mineral elements investigated, both in peel and pulp. Limoncei peel resulted also rich in $\mathrm{K}, \mathrm{Ca}$ and $\mathrm{Mg}$ while Cigulins was particularly rich in $\mathrm{Mg}$ and $\mathrm{K}$ together with Bella Donna.

The PCA plot for pulp extracts (Fig. 2) confirms Limoncei and Gala higher content in $\mathrm{Na}$, while the lowest for Red Delicious. Potassium is the most present element, in Cigulins, Bella Donna and Marcpanara, that is rich also in $\mathrm{Mg}$. Golden Delicious confirms its highest content in $\mathrm{Ca}$ also in pulp followed by Dal Doc and Dal Cordon.

No data available in literature were found to compare these results, up to our knowledge only Agnolet et al. [9] compared commercial and old apples cultivars growth in South Tyrol, for dietary elements, and Feliciano et al. [25] in Portugal, but their results referred to the whole fruit, where old cultivars showed higher amounts in $\mathrm{Mg}$, but lower in $\mathrm{Ca}$.

A correlation study among elements content has been performed. Good positive correlation in commercial apples resulted between $\mathrm{K}$ and $\mathrm{Ca}$ and an inverse correlation between $\mathrm{Na}$ and $\mathrm{Mg}$ both in pulp and peel. In old varieties only a strong correlation in peel between $\mathrm{K}$ and $\mathrm{Mg}$ was observed.

Similarly, in the two groups of samples, the content of K and the content of $\mathrm{Ca}$ in pulp strongly correlated with the correspondent content in peel, while Na content in pulp was related to the content of $\mathrm{Na}$ in peel only for ancient fruits.

Fruits poor in $\mathrm{Ca}$ have low storage potential because $\mathrm{Ca}$ plays a critical role in ripening, senescence processes and resistance to pathogens, particularly important is the balance $\mathrm{K} / \mathrm{Ca}$. Moreover, because $\mathrm{K}$ is antagonist to both $\mathrm{Ca}$ and $\mathrm{Mg}$, if $\mathrm{K}$ increases in the soil over the normal range, both $\mathrm{Ca}$ and $\mathrm{Mg}$ uptake may decrease. Several aspects may cause
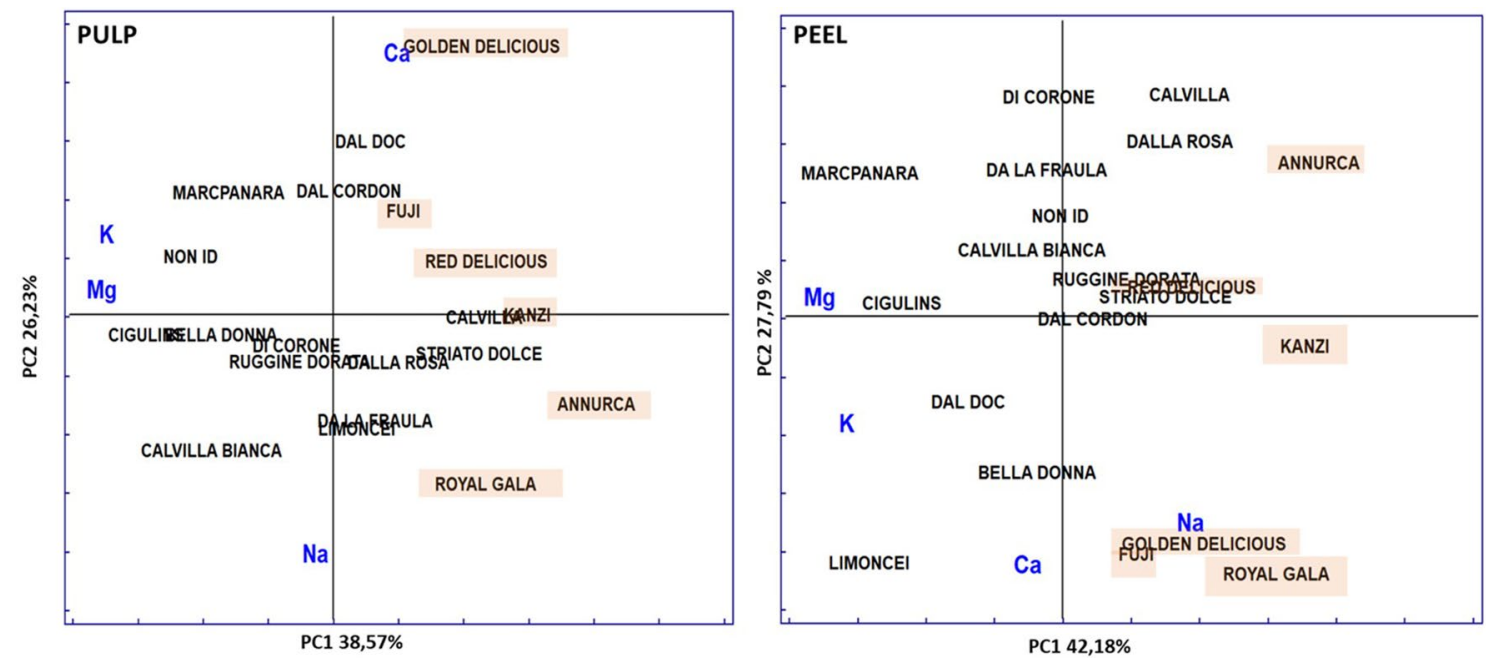

Fig. 2 Principal component analysis of macroelements composition in commercial (highlighted in pink) and ancient apple cultivars from Friuli Venezia Giulia, pulp and peel 
differences in mineral composition in different varieties and within different tissues of the same fruit, including genotype, soil type, agricultural practices, and climatic conditions [41].

In this contest, our results could be attributed to a more controlled agricultural practices in commercial apples orchards that involve $\mathrm{K}$ supplementation in the orchard management practices as a key factor in the production of high and qualitative yields of apples, this hypothesis needs a more controlled study to be verified.

\section{Conclusions}

In this study, the antioxidant capacity, polyphenolic and major minerals composition of 14 ancient apple cultivars from Northeast Italy were investigated. The results showed a great variability in the cultivars studied and a much higher content in beneficial compounds in the ancient apples respect to commercial varieties, even more than Annurca, which is considered a nutraceutical fruit. Moreover, important flavonols such as rutin and quercetin were present only in ancient cultivars pulp.

In particular, the pulp of Dalla Rosa and Limoncei cultivars was characterized by a high content in phloridzin, a dihydrocalchone whose strong antioxidant and antidiabetic power has been recently demonstrated. Ruggine Dorata and Limoncei cultivars pulp show a high content of catechins and achieved the strongest antioxidant capacity in vitro. Ancient apples of Northeast Italy showed also a good level in $\mathrm{K}$ and $\mathrm{Mg}$, fundamental minerals for the correct functioning of many physiological processes. Apple peel confirms its nutraceutical value, as to be recommended to eat the whole fruit to completely exploit its functional ingredients.

The importance of an exhaustive characterization of all ancient apple varieties present in a territory can highlight the beneficial properties linked to a peculiar genotype, that can be a source of genes in conducted breeding programs. Infact, a high content in polyphenols can, on the other side, confer to the fruit unpleasant organoleptic or agronomic attributes, such as astringent taste or greater vulnerability to enzymatic browning. Modern techniques of hybridization can overcome these aspects, exploiting the invaluable reservoir of crop genetic variability to breed novel hybrids able to match the better sensory attributes to high nutraceutical properties, better resistance to parasites, different times of ripening, to minimize agricultural interventions as chemical treatments. The market is increasingly orientated towards the production of this "perfect apple" and therefore the valorisation of autochthonous varieties biodiversity could lead also to a sustainable economic and social development of local agricultural realities. Future developments include the enlargement of the sample set as to have a comprehensive database of Friuli Venezia Giulia cultivars including a complete sensory evaluation to support strategies of commercial promotion.

Funding Open access funding provided by Università degli Studi di Roma La Sapienza within the CRUI-CARE Agreement.

\section{Compliance with ethical standards}

Conflict of interest The authors declare no conflict of interest.

Compliance with ethics requirements This article does not contain any study with human or animal subjects.

Open Access This article is licensed under a Creative Commons Attribution 4.0 International License, which permits use, sharing, adaptation, distribution and reproduction in any medium or format, as long as you give appropriate credit to the original author(s) and the source, provide a link to the Creative Commons licence, and indicate if changes were made. The images or other third party material in this article are included in the article's Creative Commons licence, unless indicated otherwise in a credit line to the material. If material is not included in the article's Creative Commons licence and your intended use is not permitted by statutory regulation or exceeds the permitted use, you will need to obtain permission directly from the copyright holder. To view a copy of this licence, visit http://creativecommons .org/licenses/by/4.0/.

\section{References}

1. Kalinowska M, Bielawska A, Lewandowska-Siwkiewicz H, Priebe W, Lewandowski W (2014) Apples: content of phenolic compounds vs. variety, part of apple and cultivation model, extraction of phenolic compounds, biological properties. Plant Physio Biochem 84:169-188

2. Li AN, Li S, Zhang YJ, Xu XR, Chen YM, Li HB (2014) Resources and biological activities of natural polyphenols. Nutrients 6:6020-6047

3. Espinoza Zúñiga C, Jarolmasjed S, Sinha R, Zhanga C, Kalcsits L, Dhingra A, Sankaran S (2017) Spectrometric techniques for elemental profile analysis associated with bitter pit in apples. Postharvest Biol Technol 128:121-129

4. Lo Piccolo E, Landi M, Massaia R, Remorini D, Conte G, Guidi L (2019) Ancient apple cultivars from Garfagnana (Tuscany, Italy) a potential source for 'nutrafruit' production. Food Chem 294:518-525

5. Sut S, Zengin G, Maggi F, Malagoli M, Dall'Acqua S, (2019) triterpene acid and phenolics from ancient apples of Friuli Venezia Giulia as nutraceutical ingredients: LC-MS study and in vitro activities. Molecules 24:1109-1124

6. Valvi SR, Rathod VS (2011) Mineral composition of some wild edible fruits from Kolhapur District. Int J appl biol pharm 2:392-396

7. Carbone K, Giannini B, Picchi V, Lo Scalzo R, Cecchini F (2011) Phenolic composition and free radical scavenging activity of different apple varieties in relation to the cultivar, tissue type and storage. Food Chem 127:493-500

8. Wolfe KL, Hai R (2003) Apple peels as a value-added food ingredient. J Agric Food Chem 51:1676-1683 
9. Agnolet S, Ciesa F, Soini E, Cassar A, Matteazzi A, Guerra W, Obatscher P, Storti A, Baric S, Dalla Via J, Oberhuber M (2017) Dietary elements and quality parameters of 34 old and eight commercial apple cultivars grown at the same site in South Tyrol, Italy. Erwerbs-Obstbau 59:171-183

10. Dalla Via J, Mantinger H (2012) Agricultural research in the field of fruit growing in South Tyrol. Erwerb Obstbau 54:83-115

11. Oszmiański J, Lachowicz S, Gamsjäger H (2020) Phytochemical analysis by liquid chromatography of ten old apple varieties grown in Austria and their antioxidative activity. Eur Food Res Technol 246:437-448

12. Jakobek L, García-Villalba R, Tomás-Barberán FA (2013) Polyphenolic characterisation of old local apple varieties from Southeastern European region. J Food Comp Anal 31:199-211

13. Vrhovsek U, Rigo A, Tonon D, Mattivi F (2004) Quantitation of polyphenols in different apple varieties. J Agric Food Chem 52:6532-6538

14. Murata N, Noda I, Seiichi H (1995) Enzymatic browning of apples on the market: relationship between browning, polyphenol content, and polyphenol oxidase. Nippon Shokuhin Kagaku Kaishi 42:820-826

15. Ferreira Holderbaum D, Kon T, Kudo T, Guerra MP (2010) Enzymatic browning, polyphenol oxidase activity, and polyphenols in four apple cultivars: dynamics during fruit development. HortScience 45(8): 1150-1154

16. Persic M, Mikulic-Petkovsek M, Slatnar A, Veberic R (2017) Chemical composition of apple fruit, juice and pomace and the correlation between phenolic content, enzymatic activity and browning. LWT 82:23-31

17. Kschonsek J, Wolfram T, Stöckl A, Böhm V (2018) Polyphenolic compounds analysis of old and new apple cultivars and contribution of polyphenolic profile to the in vitro antioxidant capacity. Antioxidants 7:20-34

18. Oszmiański J, Lachowicz S, Gławdel E, Cebulak T, Ochmian I (2018) Determination of phytochemical composition and antioxidant capacity of 22 old apple cultivars grown in Poland. Eur Food Res Technol 244:647-662

19. Jakobek L, Barron AR (2016) Ancient apple varieties from Croatia as a source of bioactive polyphenolic compounds. J Food Comp Anal 45:9-15

20. Eurostat (2019) Agriculture, forestry and fishery statistics-2019 edition

21. Giomaro G, Karioti A, Bilia AR, Bucchini A, Giamperi L, Ricci D, Fraternale D (2014) Polyphenols profile and antioxidant activity of skin and pulp of a rare apple from Marche region (Italy). Chem Cent J 8:45-52

22. Panzella L, Petriccione M, Rega P, Scortichini M, Napolitano A (2013) A reappraisal of traditional apple cultivars from Southern Italy as a rich source of phenols with superior antioxidant activity. Food Chem 140:672-681

23. Wandjou JGN, Sut S, Giuliani C, Fico G, Papa F, Ferraro S, Caprioli G, Maggi F, Dall'Acqua S (2019) Characterization of nutrients, polyphenols and volatile components of the ancient apple cultivar 'Mela Rosa Dei Monti Sibillini' from Marche region, central Italy. Int J Food Sci Nutr 70:796-812

24. Henríquez C, Almonacid S, Chiffelle I, Valenzuela T, Araya M, Cabezas L, Simpson R, Speisky H (2010) Determination of antioxidant capacity, total phenolic content and mineral composition of different fruit tissue of five apple cultivars grown in Chile. Chil J Agric Res 70:523-536

25. Feliciano RP, Antunes C, Ramos A, Serra AT, Figueira ME, Duarte CMM, de Carvalho A, Bronze MR (2010) Characterization of traditional and exotic apple varieties from Portugal. Part 1-nutritional, phytochemical andsensory evaluation. J Funct Foods 2:34-45

26. Todea DA, Cadar O, Simedru D, Roman C, Tanaselia C, Suatean I, Naghiu A (2014) Determination of major-to-trace minerals and polyphenols in different. Not Bot Horti Agrobo 42:523-529

27. Tarola AM, Girelli AM, D'Ascenzo F (2019) Bioactive polyphenol profiles and antioxidant activity in Italian apples varieties. Ital J Food Sci 31:243-252

28. Giannetti V, Boccacci Mariani M, Mannino P, Marini F (2017) Volatile fraction analysis by HS-SPME/GC-MS and chemometric modeling for traceability of apples cultivated in the Northeast Italy. Food Cont 78:215-221

29. Cataldi TRI, Margiotta G, Del Fiore A, Bufo SA (2003) Ionic content in plant extracts determined by ion chromatography with conductivity detection. Phytochem Analysis 14:176-183

30. Singleton VL, Orthofer R, Lamuela-Raventos RM (1999) Analysis of total phenols and other oxidation substrates and antioxidants by means of Folin-Ciocalteau reagent. Method Enzymol 299:152-178

31. Forina M, Lanteri S, Armanino C, Casolino C, Casale M, Oliveri P (2010) V-PARVUS 2010, Dip. Chimica e Tecnologie Farmaceutiche e Alimentari, University of Genova, free available at https:// www.parvus.unige.it

32. Santana-Gálvez J, Cisneros-Zevallos L, Jacobo-Velázquez DA (2017) Chlorogenic acid: recent advances on its dual role as a food additive and a nutraceutical against metabolic syndrome. Molecules 22:358-370

33. Zielinska D, Laparra-Llopis JM, Zielinski H, Szawara-Nowak D, Giménez-Bastida JA (2019) Role of apple phytochemicals, phloretin and phloridzin, in modulating processes related to intestinal inflammation. Nutrients 11:1173-1185

34. Mikulic Petkovsek M, Slatnar A, Stampar F, Veberic R (2011) Phenolic compounds in apple leaves after infection with apple scab. Biol Plant 55:725-732

35. D'Angelo S, Cimmino A, Raimo M, Salvatore A, Zappia V, Galletti P (2007) Effect of reddening-ripening on the antioxidant activity of polyphenol extracts from cv. 'Annurca' apple fruits. J Agric Food Chem 55:9977-9985

36. Zizkova P, Stefek M, Rackova L, Prnova M, Lubica H (2017) Novel quercetin derivatives: from redox properties to promising treatment of oxidative stress related diseases. Chem Biol Interact 256:36-46

37. Mari A, Tedesco I, Nappo A, Russo GL, Malorni A, Carbone V (2010) Phenolic compound characterisation and antiproliferative activity of "Annurca" apple, a southern Italian cultivar. Food Chem 123:157-164

38. Drogoudi P, Michailidis Z, Pantelidis G (2008) Peel and flesh antioxidant content and harvest quality characteristics of seven apple cultivar. Sci Hortic 115:149-153

39. Stanger M, Steffens C, Soethe C, Moreira M, Amarante C (2017) Phenolic content and antioxidant activity during the development of 'Brookfield ${ }^{\circledR}$ ' and 'Mishima' apples. J Agric Food Chem 65:3453-3459

40. Nour V, Trandafir I, Ionica MM (2010) Compositional characteristics of fruits of several apple (Malus domestica Borkh.) cultivars. Not Bot Horti Agrobo 38:228-233

41. Brunetto G, Bastos De Melo GW, Toselli M, Quartieri M, Tagliavin M (2015) The role of mineral nutrition on yields and fruit quality in grapevine, pear and apple. Rev Bras Frutic 37:1089-1104

Publisher's Note Springer Nature remains neutral with regard to jurisdictional claims in published maps and institutional affiliations. 